\title{
Passing the torch
}

\section{Transmettre le flambeau}

$\mathrm{T}$ his issue of the Journal marks a couple of milestones. First, this represents the 25th anniversary of the first issue of The Canadian Journal of Cardiology (CJC). Second, after 13 years, it represents my last issue as Editor-in-Chief.

The first issue of the Journal was published in January 1985, with the late Dr Bob Beamish as Editor-in-Chief, a position he held for 12 years. It is appropriate to reflect on that first issue for a number of reasons. First, in 1985, Pulsus Group Inc established the Journal with no more than a hope that it would become the official journal of the Canadian Cardiovascular Society (CCS).

Interestingly, I was one of a number of CCS members who were outspoken opponents to the Journal, believ-

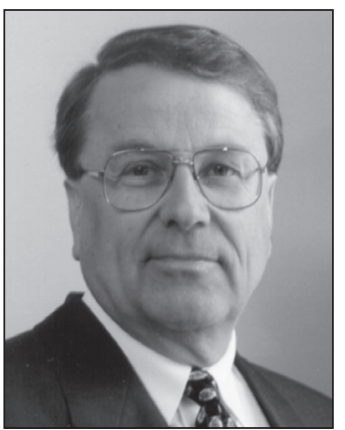

Eldon R Smith
T e présent numéro du journal souligne quelques grandes Létapes. D'abord, il marque le 25e anniversaire du premier numéro du Journal canadien de cardiologie (JCC). Ensuite, après 13 ans de services, il représente mon dernier numéro à titre de rédacteur en chef.

Le premier numéro du journal a été publié en janvier 1985. Feu le docteur Bob Beamish en était le rédacteur en chef, et il l'est demeuré pendant 12 ans. Il convient de revenir sur ce premier numéro pour plusieurs raisons. D'abord, en 1985, lorsque Pulsus Group Inc. a lancé le journal, son statut de journal officiel de la Société canadienne de cardiologie (SCC) n'était alors qu'un simple souhait.

Fait intéressant, j'étais l'un des quelques membres de la SCC à s'opposer vertement au journal, convaincu que le milieu canadien des sciences cardiovasculaires était trop ing that the Canadian cardiovascular science community was too small to support a high-quality journal. But through the persistence of Mr Robert Kalina of Pulsus Group Inc, and of Dr Beamish, the CJC was successful in becoming indexed (not an insignificant achievement) and was being recognized internationally as the de facto 'Canadian' journal of cardiology. In 1990, I was President of the CCS when it was decided that we should explore with Mr Kalina his invitation to have the CJC named as the official journal of the CCS. These negotiations were successful and since 1990, the CJC has been the official journal of the CCS. It was perhaps ironic that in 1997, when Dr Beamish retired, it was I who succeeded him as Editor-in-Chief. And now, 13 years have passed.

It is also of interest to look at some of the articles published in that first issue. There were papers authored or co-authored by (now Senator) Wilbert Keon, Drs John McCans, George Klein, William Kostuk, Charles Pollick, Martin Gardner, Naranjan Dhalla, Grant Pierce and the late Dr Robert Burns, among others. It is clear that Dr Beamish was successful in influencing these prominent Canadian cardiovascular clinician-scientists to devote time to writing papers for a journal that would not be indexed for years to come. I take my hat off to Mr Kalina, Dr Beamish and all of these authors for this 'Premiere Issue'.

The past 13 years have been interesting and therefore, often challenging, while at the same time, very enjoyable. Because the CJC is the official journal of the CCS, the CCS Council has had the responsibility of recruiting and evaluating the Editor-in-Chief. The CCS Council only recently came to grips with the realization that it was not possible to view the Journal as a significant revenue centre and communication vehicle for members while simultaneously creating a journal with a high international recognition and a high impact factor. This has created many challenges for the editor, and perhaps mistakenly, we tried to achieve both goals simultaneously. To this end, the CJC has published statements, positions and guidelines from the CCS. In addition, we have looked favourably on articles considered to be of potential importance to policy development in Canada. Both groups of publications have not always supported the goal of improving the impact factor of the Journal.

There have been other challenges associated with being the Editorin-Chief. In some instances, we developed strategies to deal with these challenges, which have been both a success and, subsequently, a failure. During the early days of my editorship, it was clear that we needed petit pour soutenir un journal de qualité. Toutefois, grâce à la persistance de monsieur Robert Katrina de Pulsus Group Inc. et du docteur Beamish, le JCC a réussi à se faire indexer (ce qui n'est pas un mince exploit) et à être reconnu sur la scène internationale comme, de fait, le journal «canadien » de cardiologie. En 1990, je présidais la SCC lorsqu'on a décidé d'évaluer avec monsieur Kalina la possibilité de favorables, et depuis cette année-là, le JCC a acquis ce statut. Il est peut-être ironique de constater qu'en 1997, lorsque le docteur Beamish a pris sa retraite, c'est moi qui lui ai succédé à la rédaction en chef. Et maintenant, treize années ont passé.

Il est également intéressant de parcourir quelques-uns des articles publiés dans ce premier numéro. Des textes étaient rédigés ou corédigés par Wilbert Keon (devenu sénateur), les docteurs John McCans, George Klein, William Kostuk, Charles Pollick, Martin Gardner, Naranjan Dhalla, Grant Pierce et feu Robert Burns, entre autres. De toute évidence, le docteur Beamish avait réussi à inciter ces scientifiques-cliniciens canadiens réputés à se consacrer à la rédaction d'articles pour un journal qui ne serait pas indexé avant des années. Je lève mon chapeau à monsieur Kalina, au docteur Beamish et à tous ces auteurs du «premier numéro ».

Les treize dernières années se sont révélées intéressantes, souvent exigeantes, mais très agréables. Puisque le JCC est le journal officiel de la SCC, le conseil de la SCC est responsable de recruter et d'évaluer le rédacteur en chef. Ce n'est que tout récemment que le conseil de la SCC a compris l'impossibilité de percevoir le journal comme un centre de revenu important et un véhicule de communication pour les membres tout en s'assurant une réputation internationale enviable et en maintenant un facteur d'impact élevé. Cette situation a suscité de nombreux défis, et peut-être à tort, nous avons tenté de réaliser les deux objectifs simultanément. À cet effet, le JCC a publié des documents de principes, des positions et des lignes directrices de la SCC et a vu d'un œil favorable les articles susceptibles d'être importants pour le développement des politiques au Canada. Ces deux groupes de publications n'ont pas toujours contribué à l'objectif d'accrô̂tre le facteur d'impact du journal.

D'autres défis se sont associés au poste de rédacteur en chef. Dans certains cas, nous avons élaboré des stratégies pour y faire face, qui ont été une réussite puis se sont transformées en échec. Aux premiers temps de ma fonction, il était évident que nous avions besoin faire du JCC le journal officiel de la SCC. Les négociations ont été 
to attract more submissions. We were successful in this goal but then, the global economic conditions conspired to make this a less desirable outcome. The more articles a journal attracts, the more resources must be devoted to evaluation of these articles and, of course, there is a significant impact of accepting more papers for publication - at least unless the total number of published articles increases. Although we were successful in increasing the number of submissions by a factor of close to 8 , as advertising revenues decreased over the past few years, we had to look at ways to discourage some of these submissions. Thus, we instituted a fee to have a manuscript evaluated, an intervention that clearly had a negative impact on submission numbers from the international community. In addition, as advertising revenues decreased, we were forced to publish fewer articles in fewer issues per year - interventions that have resulted in much longer wait times for publication of accepted articles and therefore, less incentive for authors to submit to the CJC. This has made the past two years particularly difficult as we have struggled to decrease the delay time to publication while wishing to continue to attract and accept good articles submitted to the Journal. I believe we have made significant progress. Although our total number of submissions has decreased by approximately one-third in the past two years, our acceptance rate has remained relatively low and because of online publication, we have been successful in clearing most of the backlog of articles accepted earlier for publication. At the same time, we have taken some positive steps toward decreasing the number of published articles considered in the calculation of our impact factor. As a result, the impact factor for 2008 increased to our highest level ever at 1.8, and we have every reason to believe that it will increase further for the 2009 year. Thus, despite some very difficult economic times during which we have decreased the number of issues per year and the number of papers per issue, we have managed to continue to publish articles of importance to Canadian cardiovascular medicine and at the same time, increased our impact factor. However, it needs to be noted that many of our authors have had to suffer long waits to publication during this difficult time and for this, we offer both our apologies and our appreciation.

And now it is time to pass the torch. I am delighted that the CCS has been successful in recruiting Dr Stanley Nattel of the Montreal Heart Institute (Montreal, Quebec) for the position of Editor-inChief. Dr Nattel is a successful researcher who brings a long record of experience in editing to the CJC and I am confident that he is ideally situated to lead the Journal to the next level of accomplishment. I sincerely believe that with Dr Nattel's leadership, the CJC can move into the upper echelons of international cardiovascular journals, while at the same time, continuing to serve the Canadian cardiovascular community needs. This will not occur without challenges, and Dr Nattel and the CJC will need the support of our authors, reviewers and readers as we move forward. But I believe that while challenges exist, the future is bright. I will be watching attentively from the sidelines and am prepared to do whatever I can to support the future success of the Journal.

I wish to thank the CCS for the opportunity to be the Editor-inChief, as well as Pulsus Group Inc (Mr Kalina and staff) for all their d'attirer plus de propositions. Nous y avons réussi, mais le climat économique mondial a conspiré pour rendre cet objectif moins souhaitable. Plus un journal attire d'articles, plus il a besoin de ressources pour les évaluer, sans compter que l'acceptation d'un plus grand nombre d'articles a des répercussions importantes, sauf si le total d'articles publiés augmente. Nous avons réussi à accroître d'un facteur de près de 8 le nombre de propositions, mais comme les revenus de publicité diminuent depuis quelques années, nous avons dû chercher à en décourager certaines. C'est pourquoi nous avons instauré des frais pour faire évaluer les manuscrits, une intervention qui a nui indubitablement au nombre de propositions émanant de la communauté internationale. De plus, puisque le nombre de publicitaires diminuait, nous avons été forcés de publier moins d'articles et moins de numéros par année, une intervention qui a rallongé l'attente avant la publication des articles acceptés et, par conséquent, a moins incité les auteurs à proposer des articles au JCC. Les deux dernières années ont ainsi été particulièrement difficiles parce que nous avons cherché à réduire le délai avant la publication tout en espérant continuer d'attirer et d'accepter de bons articles. Je pense que nous avons réalisé des progrès importants. Même si le total des propositions a diminué d'environ le tiers depuis deux ans, notre taux d'acceptation est demeuré relativement faible et, grâce aux publications électroniques, nous avons réussi à dégager la plupart des articles accumulés déjà acceptés pour publication. Parallèlement, nous avons pris des mesures positives vers la réduction du nombre d'articles publiés envisagés pour le calcul du facteur d'impact. Par conséquent, le facteur d'impact pour 2008 a atteint un taux de 1,8, le plus élevé de notre histoire, et nous avons toutes les raisons de croire qu'il augmentera encore pour 2009. Ainsi, malgré une période économique très difficile pendant laquelle nous avons réduit le nombre de numéros par année et le nombre d'articles par numéro, nous avons réussi à continuer de publier des articles d'importance pour la médecine cardiovasculaire au Canada tout en accroissant notre facteur d'impact. Nous devons toutefois souligner que bon nombre des auteurs ont dû subir une longue période d'attente. Nous nous en excusons et nous les remercions.

Le temps est venu de transmettre le flambeau. Je suis ravi que la SCC ait réussi à recruter le docteur Stanley Nattel de l'Institut de cardiologie de Montréal, au Québec, au poste de rédacteur en chef. Le docteur Nattel est un chercheur fécond qui apporte au JCC sa longue expérience de rédacteur. À mon avis, il est extrêmement bien placé pour mener le journal au niveau de réalisations suivant. Je suis convaincu que, grâce aux qualités de chef du docteur Nattel, le JCC peut franchir de nouveaux échelons au sein des journaux de cardiologie internationaux tout en répondant aux besoins du milieu canadien de la cardiologie. Ce ne sera pas sans défis; le docteur Nattel et le JCC auront besoin du soutien des auteurs, des réviseurs et des lecteurs tandis qu'ils iront de l'avant. Je pense toutefois que malgré les défis, l'avenir est lumineux. J'observerai attentivement, car je suis prêt à faire tout ce qui est en mon pouvoir pour soutenir la future réussite du journal. 
support over the years. I have learned much and hope I have contributed in some small way to Canadian cardiovascular medicine and the development of the CJC. I owe much to the Associate Editors, members of the Editorial Board, Ms Peggy Randall in my office, and particularly to the many reviewers for all their support over the years. I will miss it.

Eldon R Smith OC MD FRCPC Editor-in-Chief

The views expressed on this page are those of the Editor-in-Chief and are not intended to reflect the opinions of the Canadian Cardiovascular Society or Pulsus Group Inc.
Je tiens à remercier la SCC de m'avoir donné la possibilité d'être rédacteur en chef, ainsi que Pulsus Group Inc. (monsieur Kalina et le personnel) de tout leur soutien au fil des ans. J'ai beaucoup appris et j'espère avoir apporté ma petite pierre au milieu canadien de la cardiologie et au développement du JCC. Je dois beaucoup aux rédacteurs adjoints, aux membres du comité de rédaction, à madame Peggy Randall de mon bureau et, surtout, aux nombreux réviseurs pour leur appui au cours des années. Ça me manquera.

Eldon R Smith OC MD FRCPC Rédacteur en chef

Le présent point de vue n'engage que le rédacteur en chef et ne reflète pas nécessairement celui de la Société canadienne de cardiologie ou de Pulsus Group Inc.

\section{REPRINT OF THE JOURNAL'S FIRST EDITORIAL}

\section{A New Cardiovascular Journal}

$P^{\text {ind }}$ roduction of another medical journal, even one limited to the single system of the heart and circulation, is not to be undertaken lightly. At present there are many journals competing for the limited reading time of physicians, surgeons and researchers, each with its own standard of excellence and each with a content and a style of its own. Some of them are of primary interest to practicing cardiovascular physicians or surgeons, while others are mainly concerned with research or clinical investigation. The ever increasing circulatory technologies have also given rise to additional new publications. Not only has the number of journals increased but the size of some has become positively intimidating. The solution for the reader is to read selectively from a larger number of publications.

This plethora of information and opinion is not to be decried nor regretted because it is simply a reflection of the enormous growth in knowledge of the heart and circulation, in both health and disease, that has occurred in the past half century. The progress and change in diagnosis, treatment and prevention of cardiovascular disease compares favorably with the phenomenal advances in communication and transportation achieved during this century.

Due to the large and effective financial support of the Canadian Heart Foundation, the Medical Research Council, and others, Canadian contributions to practice and research in cardiology have been substantial.
However, they have not always been properly credited because they have been published in journals of other countries. While The Canadian Journal of Cardiology will welcome manuscripts from any part of the world, it will be a needed medium for dissemination of the increasing volume of papers arising in this country. Either of the two official languages, English or French, may be used. Publication within six months of accepted manuscripts will be a primary objective.

In an effort to meet these several demands The Canadian Journal of Cardiology has appointed associate editors with special responsibilities for clinical cardiology, cardiovascular surgery, pediatric cardiology and experimental cardiology. Additionally, an Editorial Board and an International Advisory Board with wide-ranging interests and expertise have been recruited. The Journal invites original papers, reviews, reports of symposia, case reports, editorials on timely topics, letters to the editor, and news or announcements of interest to the cardiovascular community. While it is impossible to create a journal that pleases everyone all of the time, the Editorial Board is dedicated to fulfilling a need with a journal of world-class quality.

R.E. Beamish, M.D. Editor-in-Chief

Originally published in 1985;1(1):7 